Original article

\title{
Association of signal transducer and activator of transcription 4 gene (restriction site7582694) single nucleotide polymorphism with systemic lupus erythematosus
}

\author{
Hamdan Hamid ${ }^{1}$, Nadeem Afzal ${ }^{2}$, Muhammad Kashif ${ }^{1}$, Muhammad Adil Bashir ${ }^{1}$, Shah Jahan ${ }^{2}$ \\ 1 Bakhtawar Amin Medical and Dental College, Multan, Pakistan \\ 2 University of Health Sciences, Lahore, Pakistan
}

Received 11 September 2020, Accepted 5 February 2021

(C) 2020, Hamid H., Afzal N., Kashif M., Bashir M.A., Jahan S.

(C) 2020, Russian Open Medical Journal

Abstract: Background - Systemic lupus erythematosus (SLE) is an inflammatory autoimmune disease characterized by production of autoantibodies and deposition within various organs. The incidence of SLE averages 5 cases per 100,000 population. Various genome wide studies have shown association of STAT4 (signal transducer and activator of transcription 4) gene with SLE and lupus nephritis (LN). Therefore, this study was designed to determine single nucleotide polymorphism (SNP) in STAT4 (rs7582694) in local SLE, LN patients and healthy controls.

Objective - To determine the frequency of STAT4 (rs7582694) gene polymorphism in systemic lupus erythematosus, lupus nephritis patients and healthy controls.

Methods - It was a case-control study. Eighty samples were recruited for each of two study groups. Deoxyribonucleic acid (DNA) extraction was carried out using standard phenol chloroform method. Further, samples were processed by polymerase chain reactionrestriction fragment length polymorphism (PCR-RFLP) conventional technique and genotypes were determined. Polymorphism analysis and allele frequencies were compared between groups using the chi-square test. Project was approved by the Ethical Review Board at the University of Health Sciences, Lahore, Pakistan.

Results - Females were more inclined towards developing SLE. The study unveiled that SNP in STAT 4 gene (rs7582694) was associated with SLE patients in Pakistani population which indicates that this may play a role in susceptibility to SLE. Moreover, we infer that genetic variations within STAT4 (rs7582694) predispose patients to lupus nephritis. It was also evident that GG and GC genotypes were more susceptible of further transforming into SLE and LN.

Conclusion: The findings of this study may contribute to a better understanding of underlying etiological and prognostic factors regarding SLE and LN.

Keywords: signal transducer and activator of transcription 4, systemic lupus erythematosus, lupus nephritis, single nucleotide polymorphism.

Cite as Hamid H, Afzal N, Kashif M, Bashir MA, Jahan S. Association of signal transducer and activator of transcription 4 gene (restriction site7582694) single nucleotide polymorphism with systemic lupus erythematosus. Russian Open Medical Journal 2021; 10 : e0107.

Correspondence to Hamdan Hamid. Phone: +923334545340. Email: kh.hamdan99@gmail.com.

\section{Introduction}

Systemic lupus erythematosus (SLE) is an autoimmune inflammatory disorder, characterized by extensive autoantibody production and formation of immune complex (IC) within tissues. Inflammation in kidneys, skin, joints, heart and central nervous system are the hallmarks of SLE [1].

The incidence of SLE averages 5 cases per 100,000 population and Center for Disease Control (CDC)-Atlanta estimated 1.8 to 7.6 per 100,000 people effected with SLE per year in the United States of America. The reported prevalence of SLE was about 52 cases per 100,000 population. The Lupus Foundation of America had projected the prevalence of SLE as up to 1.5 million. In a survey from the National Arthritis Data Working Group, approximately 250,000 Americans had SLE [2].
SLE affects females more frequently than males and it is 9 times more evident in females, suggesting male to female ratio of 1:9 [3]. Moreover, Asians possess an increased disease prevalence affecting 100 women per 100,000 [4]. This dominance of SLE in females is possibly due to the presence of paired $X$ chromosomes in females comparatively presence of a single $X$ chromosome in males. The $X$ chromosome carries peculiar genes, which can mutate and contribute to the onset of SLE. The $Y$ chromosome has no identified mutations correlating with autoimmune disease [5]. Epidemiologic data also reveals an increased concordance of monozygotic twins (24-69\%) as compared to dizygotic twins or siblings (2-5\%) in SLE. This finding has justified the role of genetics in SLE [6].

In 1997 the American College of Rheumatology (ACR), established eleven diagnostic criteria for SLE. Patient presenting 
with any four of these can be diagnosed as SLE. Those criteria are as follows:

Malar rash, discoid (skin) rash, photosensitivity, mouth or nose ulcers: usually painless, arthritis (non-erosive) in two or multiple joints, cardio-pulmonary involvement, neurologic disorder, renal disorder, hematologic disorder, immunologic disorder: presence of anti-double stranded deoxyribonucleic acid (anti-ds DNA), antismooth muscle $(\mathrm{Sm})$ or anti-cardiolipin antibody and anti-nuclear antibody (ANA) tests positivity [7].

According to ACR classification criteria, presence of $0.5 \mathrm{~g}$ of protein per 24 hours or a dipstick score of more than $3+$ or the presence of casts on microscopic analysis of spun urine that includes red blood cells, granular, tubular or mixed casts confirms the diagnosis of lupus nephritis (LN) [8]. In addition, renal biopsy is a definitive way for assessing the damage to renal tissue [9].

Three immunological pathways are found to be involved in the pathogenesis of SLE: innate immune response including Toll-like receptor (TLR)/Interferon (IFN) signaling pathways, adaptive immune response depending upon $\mathrm{B}, \mathrm{T}$ lymphocytes and antigen presenting cells (APCs) immune signal transduction and IC clearance mechanism [10].

Pathogenesis of SLE involves, both type-II and type-III hypersensitivity reactions, in which bound antigen-antibody IC accumulate and culminate in further immune responses [11]. Impaired apoptosis exposes the nuclear and cytoplasmic antigens, while defects in IFN and TLR signaling pathways induce IC containing self-nucleic acids. Further, they interact with signal transducer and activator of transcription 4 (STAT4) and interferon regulatory factors within plasmocytic dendritic cells (PDCs) and B cells endosomes, resulting in the production of type I IFN and interleukin (IL)-6 [12]. Stimulation of both B cell receptors (BCRs) and TLRs trigger auto reactive $B$ cell proliferation. Their further differentiation into plasma blasts is induced by type I IFN and into autoantibody secreting plasma cells collectively mediated by (IL)- 6 . The overall effect of all these variations executes diversified autoantibodies production, complement activation, IC deposition and inflammation, which later on leads to pathological changes in skin, kidneys, heart, lungs, nervous system and hematopoietic organs $[10,11]$

STAT4 gene encodes a transcription factor that can be triggered by (IL)-12 and (IL)-23, which plays a key role in the signaling of type I IFN receptor [12]. Physiologically, STAT4 plays a crucial role in the immunological response. Pathologically, STAT4 contributes in the production of autoantibodies, prevention of apoptosis and presentation of auto antigens [13, 14].

Etiopathogenesis of SLE still remains uncertain whereas it possesses environmental and genetic predispositions [4]. Like various other diseases, Human leukocyte antigen (HLA) has important contribution towards SLE. HLA-DR2 and HLA-DR3 possess the major risk loci for SLE [15]. It is evident from a study in Pakistan that there is a strong association of HLA with SLE [16]

Various genome-wide association studies (GWAS) have depicted association of STAT4 with SLE patients among different ethnic groups. The findings explained the association of various single nucleotide polymorphisms (SNPS) across STAT4 and the STAT1-STAT4 intragenic regions with SLE [17]. A study in Chinese population has shown significant association of STAT4 (rs7582694) with SLE and LN patients alongside other factors [18]. Few studies have also demonstrated association between LN and STAT4. A study in Swedish LN patients revealed their disease association with four SNPs in STAT4; rs11889341, rs7574865, rs7568275 and rs7582694 [19].

It is evident from various studies that STAT4 SNPs may be considered as major genetic risk factors for developing SLE and further in to LN. In that context, the present study has been designed to determine the frequency of SNP in rs7582694 of STAT4 gene in local SLE, LN patients and healthy controls.

\section{Material and Methods}

It was a case-control study. This study was conducted in the Department of Immunology and Resource Lab, UHS Lahore after approval by the Ethical Review Board and Advance Studies and Research Board UHS, Lahore, Pakistan. Samples were collected from Rheumatology Clinic-Fatima Memorial Hospital, Lahore after approval by the Ethical Review Committee of Fatima Memorial Hospital. Control samples were recruited from attendants of patients and healthy population of UHS after prior consent from the subjects and acquisition of complete history.

The sample size was calculated by the statistical formula keeping the power of study equal to $80 \%$ and level of significance equal to $5 \%$. The calculated sample size was 80 in each group. Convenience sampling technique was applied.

Group I: Apparently healthy controls.

Group II: SLE patients.

\section{Inclusion criteria}

Controls:

- Both male and female between 18-60 years of age.

- Healthy individuals

Cases:

- Both males and females between 18-60 years of age.

- Diagnosed SLE patients based on ACR diagnostic criteria.

Exclusion criteria:

- Subject with history of recent infection in last two weeks.

- Patients with autoimmune disease other than SLE.

- Other chronic conditions (Diabetes mellitus).

- Malignancy

\section{Blood sample collection}

Three (3) $\mathrm{ml}$ of venous blood were collected in ethylene diamine tetra-acetic acid (EDTA) coated vacutainer tubes from SLE patients and control groups. Samples were brought to the Department of Immunology in an ice box $\left(4^{\circ} \mathrm{C}\right)$ immediately after collection and were stored at $-20^{\circ} \mathrm{C}$ until DNA extraction.

\section{Sample processing}

Deoxyribonucleic acid (DNA) extraction from whole blood was carried out in the Department of Immunology UHS, Lahore by using phenol and chloroform [20]. The extracted DNA was stored at $-20^{\circ} \mathrm{C}$ till further processing. Complete blood counts were performed on Sysmex XE-2100 instrument while ESRs were estimated on Vesmatic Cube30 instrument. 


\section{Extraction of human genomic DNA}

DNA was extracted from $3 \mathrm{ml}$ blood of all the patients by using standard Phenol-Chloroform method and dissolved in $200 \mathrm{ul}$ of 0.1 M TE buffer [20]. Concentration and integrity of extracted DNA was determined by spectrophotometer and agarose gel electrophoresis respectively. After quantifying DNA concentration, $25 \mathrm{ng} / \mu \mathrm{L}$ dilution of each DNA sample was prepared in PCR grade water for PCR amplification and polymorphism analysis.

Table 1. Sequences of primers for the amplification of loci

\begin{tabular}{lc}
\hline SNP & Primers \\
\hline STAT4 & F:5'ATCCAACTCTTCTCAGCCCTT3' \\
rs7582694 & R:5'TCATAATCAGGAGAGAGGAGT3' [21] \\
\hline
\end{tabular}

Table 2. Demographic data of studied subjects

\begin{tabular}{|c|c|c|c|c|}
\hline \multicolumn{2}{|c|}{ Variables } & Controls & Patients & $p$-value \\
\hline \multicolumn{2}{|c|}{ Age (Mean \pm SD) } & $30.70 \pm 7.65$ & $30.20 \pm 7.77$ & 0.984 \\
\hline \multirow{2}{*}{ Gender } & Male & 06 (7.5\%) & 06 (7.5\%) & \multirow{2}{*}{1.000} \\
\hline & Female & 74 (92.5\%) & 74 (92.5\%) & \\
\hline
\end{tabular}

$n$, number; \%, percentage; $p$-value $<0.05$, statistically significant.

Table 3. Percentages of dsDNA and ANA in SLE patients

\begin{tabular}{lc}
\hline Variables & Patients $(n=80)$ \\
\hline Anti dsDNA & $76(95 \%)$ \\
ANA & $73(91.25 \%)$ \\
\hline
\end{tabular}

$\mathrm{n}$, number of patients; $\%$, percentage.

Table 4. Mean heamoglobin and ESR in SLE patients and healthy controls

\begin{tabular}{lccc}
\hline \multirow{2}{*}{ Variable } & \multicolumn{2}{c}{ Mean/median } & \multirow{2}{*}{-value } \\
& Group I (control, $\mathrm{n}=80)$ & Group II (SLE, $\mathrm{n}=80)$ & \\
\hline Haemoglobin & $14.100 \mathrm{~g} / \mathrm{dl}$ & $11.400 \mathrm{~g} / \mathrm{dl}$ & $<0.0001$ \\
ESR & $13.00 \mathrm{~mm} / \mathrm{hr}$ & $52.0 \mathrm{~mm} / \mathrm{hr}$ & $<0.0001$ \\
\hline
\end{tabular}

$\mathrm{n}$, number; $\mathrm{p}$-value $<0.05$; statistically significant

Table 5. Distribution of STAT 4 polymorphism in SLE patients

\begin{tabular}{lcccc}
\hline $\begin{array}{l}\text { STAT4 } \\
\text { polymorphism }\end{array}$ & $\begin{array}{c}\text { Controls } \\
n=80\end{array}$ & $\begin{array}{c}\text { Patients } \\
n=80\end{array}$ & $\begin{array}{c}\text { Odds ratio } \\
\text { OR }(\mathrm{Cl})\end{array}$ & p-value \\
\hline CC & $35(43.8 \%)$ & $15(18.8 \%)$ & Reference & \\
GC & $29(36.2 \%)$ & $39(48.8 \%)$ & $3.139(1.448-6.805)$ & 0.004 \\
GG & $16(20.0 \%)$ & $26(32.5 \%)$ & $3.825(1.568-9.226)$ & 0.003 \\
\hline
\end{tabular}

Table 6. Association of G allele (STAT4) with onset of SLE

\begin{tabular}{lcccc}
\hline \multirow{2}{*}{ Exposure (G allele) } & \multicolumn{2}{c}{ Disease $(S L E)$} & \multirow{2}{*}{ Odds Ratio(CI) } & p-value \\
\hline & Yes & No & & \\
\hline Yes & 92 & 61 & $2.171(1.168-3.764)$ & 0.003 \\
No & 69 & 99 & & \\
\hline
\end{tabular}

Table 7. Distribution of STAT 4 (rs7582694) polymorphism among SLE patients with different clinical manifestations

\begin{tabular}{lllll}
\hline Characteristic & $G G$ & $G C$ & $C C$ & Odds ratio (95\% CI) \\
\hline Malar rash & 31 & 9 & 10 & \\
Discoid rash & 5 & 13 & 7 & \\
Photosensitivity & 6 & 21 & 9 & \\
Oral or nasopharangeal & 4 & 18 & 10 & \\
Arthritis & 4 & 9 & 6 & \\
Serositis & 3 & 7 & 4 & \\
Renal & 21 & 6 & 15 & $2.212(0.581-5.834)$ \\
Neurologic & 7 & 15 & 9 & \\
Hematologic & 9 & 19 & 11 & \\
Immunologic & 25 & 8 & 21 & $2.028(0.644-6.659)$ \\
\hline
\end{tabular}

\section{Optimization of primer for amplification}

Primers (Table 1) and samples were optimized for polymerase chain reaction (PCR) with optimum reaction conditions; temperature $\left(58^{\circ} \mathrm{C}\right), \mathrm{Mg}$ concentration, buffer and dNTPs [21].

\section{Polymerase chain reaction}

Ten $\mu$ reaction mixtures of PCR amplification product constituted by $2 \mu \mathrm{l}$ of diluted DNA $(25 \mathrm{ng} / \mu \mathrm{l}), 10 \times$ Taq buffer $[10 \mathrm{mM}$ Tris- $\mathrm{HCl}\left(\mathrm{pH} 8.8\right.$ at $\left.25^{\circ} \mathrm{C}\right), 50 \mathrm{mM} \mathrm{KCl}, 0.08 \%$ (v/v) Nonidet P40], 1.5 $\mathrm{mM} \mathrm{MgCl}, 0.4 \mu \mathrm{l}$ of mixture contained $100 \mu \mathrm{M}$ of each dNTP, $5 \mathrm{nM}$ of each primer and $1 \mathrm{U}$ of Taq DNA polymerase.

Temperature profile consisted of an initial denaturation at $94^{\circ} \mathrm{C}$ for 4 minutes, 30 cycles of denaturation at $94^{\circ} \mathrm{C}$ for 30 secs, annealing at $58^{\circ} \mathrm{C}$ and extension at $72^{\circ} \mathrm{C}$ for 30 secs, followed by 5 minutes final extension step at $72^{\circ} \mathrm{C}$. iCycler PCR thermocycler (Bio-Rad, USA) was used during this experiment.

\section{Agarose gel electrophoresis}

After the completion of every PCR reaction for SNP analysis, $5 \mu \mathrm{l}$ of the PCR reaction was run on agarose gel electrophoresis to observe the genotype of each patient.

\section{RFLP analysis}

RFLP analysis was performed for single nucleotide polymorphism. Specific restriction site was identified by an endonuclease $\mathrm{HpyCH} 4 \mathrm{III}$ (Helicobacter pylori CH4III) for STAT4. For the analysis of STAT4 (rs7582694) genotype, restriction digestions of all the amplified DNA samples were carried out with $\mathrm{HpyCH} 4 \mathrm{III}$ restriction enzyme at $37{ }^{\circ} \mathrm{C}$ for 4 hours. The restriction digested PCR products were electrophoresed on $2.5 \%$ TAE agarose gel for 40 minutes along with 50bp molecular DNA size marker. The RFLP patterns were then determined under ultraviolet light. The digested product of STAT4 had three genotypes (GG), (GC), (CC). The PCR-amplified fragments of STAT 4 were $338 \mathrm{bp}$ in length and were isolated and digested with the endonuclease $\mathrm{HpyCH} 4$. The STAT $4 \mathrm{G}$ allele was cleaved into $258 \mathrm{bp}$ and 80 bp fragments, whereas the STAT $4 \mathrm{C}$ allele remained uncut.

\section{Complete blood count ESR estimation}

Complete blood counts were performed on Sysmex XE-2100 and ESR estimations were carried out on Vesmatic Cube30 instrument.

\section{Statistical analysis}

Statistical analysis was carried out using SPSS version 20.0.

\section{Results}

A total of one hundred and sixty subjects were recruited and divided into two groups. Group I was comprised of 80 healthy controls and group II was comprised of 80 diagnosed SLE and LN patients based on ACR diagnostic criteria.

Mean $( \pm S D)$ of age of the subjects with SLE (group-II) was (30.72 \pm 7.77$)$, which was almost similar to the controls (Group-I) $(30.70 \pm 7.65)$. Comparison showed there was no statistically significant difference between two groups $(p=0.984)$, as depicted in Table 2. 
The frequency of female subjects was high in both groups (Group-I 92.5\%) and (Group-II 92.5\%). Frequency of females was high in control group because we intended to keep them age- and gender-matched, as expressed in Table 2.

Among 80 SLE patients, 95\% were found to be positive for antidsDNA antibodies and $91.25 \%$ patients were detected as positive for ANA as shown in Table 3.

Level of hemoglobin within group 1 (controls) and group 2 (SLE patients) was $14.1 \mathrm{~g} / \mathrm{dl}$ and $11.4 \mathrm{~g} / \mathrm{dl}$ respectively, labeled as statistically significant. Likewise, there was significant difference between ESR levels of SLE patients and healthy controls. ESR levels were higher in SLE patients, where on an average, it was 52.5 $\mathrm{mm} /$ hour, as compared to control subjects, where it was 13.0 $\mathrm{mm} /$ hour, as cumulatively enumerated in Table 4.

Furthermore, the odds ratio for GC genotype was 3.139, while for GG genotype, it was 3.825. There was statistically significant association of these genotypes with SLE ( $p$-value for GC genotype: 0.004 and for GG genotype: 0.003 , respectively) as depicted in Table 5.

Presence of STAT4 $\mathrm{G}$ allele was positively associated with the onset of disease (SLE) with odd ratio of 2.171 and confidence interval of 1.168-3.764; this association was statistically significant with a p-value of 0.003 as shown in Table 6.

Moreover, in patients with renal manifestation, the frequencies of GG and CC genotype were 21 and 15, respectively, and it was significantly associated with these genotypes ( $O R=2.212$ [0.581-5.834]). Also, in the patients with immunological manifestations, the frequency of GG and CC genotype was 25 and 21 , respectively, and it was also significantly associated with these genotypes. (OR=2.028 [0.644-6.659]) as expressed in Table 7.

\section{Discussion}

In the present study, polymorphism in STAT 4 gene (rs7582694) was found to be associated with SLE. The mean ( \pm SD) age of the SLE subjects was $30.72 \pm 7.77$ which agreed with EI Toukhy et al., who reported the mean age as $32.50 \pm 9.09$ years [21]. Mean age of SLE patients reported by Rabbani and colleagues in 2004 was 31 years; a study formulated in Karachi, Pakistan, is also in agreement with the current study [22]. Controls were ageand gender-matched to opt for even better outcome. In the current study, the frequency of female subjects was higher (92.5\%), as compared to male subjects $(7.5 \%)$, which agrees with Jacobs et al who projected $90.7 \%$ females in the study [23]. RúaFigueroa also reported $90.5 \%$ females and $9.5 \%$ males [24]. These studies reported high frequency of females possessing SLE in comparison with males, and it has been well documented [25]

Aside from hormones and genetic disposition, an alternative plausible cause has now been reported by Abelson et al., who described the association of STAT4 with systemic lupus erythematosus [14]. In this study, ANA was detected in $91.25 \%$ of measured population. Aforementioned study is in conformity with study of Solangi et al., who documented that $88.3 \%$ ANA positivity in SLE patients [26]. Gibson et al., reported 95\% ANA positivity referring SLE patients in their study [27]. Anti-dsDNA was detected in $95 \%$ of studied population in this study. Solangi et al., documented $96.81 \%$ of anti-dsDNA in SLE patients which is congruent with this study [26]. Presence of anti-dsDNA is persistent with lupus nephritis and renal exposition of the disease as well [28]. Level of hemoglobin in group I was $14.1 \mathrm{~g} / \mathrm{dl}$, which was normal; whereas, the hemoglobin level was $11.4 \mathrm{~g} / \mathrm{dl}$ in group II. This study is in accordance with Voulgarelis et al., who reported the average hemoglobin as 9 and $11 \mathrm{~g} / \mathrm{dl}$ among both groups, respectively [29]. Similar results were also found in another study in India, the study reported hemoglobin levels as $9.5 \mathrm{mg} / \mathrm{dl}$ within SLE patients [30]. Hematological abnormalities are common in SLE patients. Decreased levels of erythropoietin are found due to chronic inflammation, renal insufficiency and presence of anti-erythropoietin autoantibodies which are assessed with European Consensus Lupus Activity Measurement (ECLAM) [31, 32]. An association between disease activity in SLE patients and activation of the type 1 interferon system has been observed [33]. The results of another study suggested that STAT4 G>C (rs7582694) intronic substitution may significantly enhance the risk of SLE occurrence in a sample of the Polish population [34]. Recent studies carried out by Luan et al., depicted a statistically significant contribution of STAT4 G>C (rs7582694) influencing incidence of SLE in the Mainland Chinese female population [35]. The association of STAT4 G>T (rs75748865) polymorphism with SLE development was also previously observed in other Asian ethnic groups residing in Hong Kong, Northern Han of China, and Japan $[4,36]$. The contribution of the STAT4 G>C (rs7582694) or STAT4 G>T (rs7574865) polymorphisms to SLE incidence was also observed in large groups of patients of European origin, among them a Finnish family cohort as well as Swedish and other populations [37-38]. A recent Iranian study by Izadkhasti et al., has concluded that there is a relationship between the STAT4 gene G/C (rs7582694) SNP and the increased risk of SLE [39]. In present study, the frequency of GG in group I was $16(20 \%)$; on the other hand, in group II, the frequency was 26 (32.5\%). Odds ratio OR (95\% $\mathrm{Cl})=3.825$ (1.586-9.226), $\mathrm{p}=0.003$. Similarly, the frequency of $\mathrm{GC}$ in group I was $29(36.2 \%)$ while in group II it was $39(48.8 \%)$. Odds ratio $\mathrm{OR}=3.139$ (1.448-6.805), $\mathrm{p}=0.004$. High odds ratio was observed in the Patients of SLE with GG compared to CC, which explained that patients possessing $\mathrm{G}$ allele may be at risk of developing SLE. These results support the finding of $\mathrm{Xu}$ et al., who reported that the frequency of the STAT4 $G$ allele was higher in patients with SLE compared with healthy individuals. Xu et al., also showed that individuals with $\mathrm{G}$ allele at $\mathrm{rs} 7582694$ possessed an increased risk of developing the disease [40-42].

Remarkably, the patients with the renal disorder manifestations possessed the frequencies of GG and CC genotypes as 21 and 15, respectively, and this finding was significantly associated with these genotypes, having an odds ratio of 2.212, which was congruent with a study carried out by Bolin et al., who discovered that STAT4 SNP (rs7582694) was associated with severe renal insufficiency $\left(p=1.6 \times 10^{-3}\right.$ with an odds ratio of 2.22$)$ [19].

\section{Conclusion}

SNP in STAT 4 gene (rs7582694) GG and GC genotypes are associated with SLE in Pakistani population which indicates that this may play some role in its susceptibility to SLE. Furthermore, we conclude that genetic variation within STAT4 (rs7582694) is associated with an outcome of severe renal insufficiency which may lead to LN. These findings may contribute to a better comprehension of the complex etiopathological factors pertaining SLE.

\section{Limitations and recommendations}

Major limitation of this study is a small sample size. If study was performed on large population and within multiple restriction 
sites; a far better understanding of STAT4 polymorphism and its influence on SLE and LN could be established. As SLE is a complex disorder with both genetic and environmental factors involved in its etiology, further research should be carried out in a larger perspective; including analysis of the combined effect of multiple loci merely circumscribing a single SNP or a singular gene. Furthermore, functional studies are required to interpret the underlying pathogenesis of SLE and its further development into LN.

\section{Conflict of interests}

None to declare

\section{Ethical approval}

All applicable international, national, and institutional guidelines for the care and use of animals were followed.

\section{References}

1. Danchenko N, Satia JA, Anthony MS. Epidemiology of systemic lupus erythematosus: a comparison of worldwide disease burden. Lupus 2006; 15(5): 308-318. https://doi.org/10.1191/0961203306lu2305xx.

2. Helmick CG, Felson DT, Lawrence RC, Gabriel S, Hirsch R, Kwoh CK, et al. Estimates of the prevalence of arthritis and other rheumatic conditions in the United States: Part I. Arthritis Rheum 2008; 58(1): 1525. https://doi.org/10.1002/art.23177.

3. Sanchez E, Nadig A, Richardson BC, Freedman BI, Kaufman KM, Kelly $\mathrm{JA}$, et al. Phenotypic associations of genetic susceptibility loci in systemic lupus erythematosus. Ann Rheum Dis 2011; 70(10): 17521757. https://doi.org/10.1136/ard.2011.154104.

4. Yang $\mathrm{W}, \mathrm{Ng} \mathrm{P}$, Zhao M, Hirankarn N, Lau CS, Mok CC, et al. Population differences in SLE susceptibility genes: STAT4 and BLK, but not PXK, are associated with systemic lupus erythematosus in Hong Kong Chinese. Genes Immun 2009; 10(3): 219-226. https://doi.org/10.1038/gene.2009.1.

5. Lu LJ, Wallace DJ, Ishimori ML, Scofield RH, Weisman MH. Review: Male systemic lupus erythematosus: a review of sex disparities in this disease. Lupus 2010; 19(2): 119-129. https://doi.org/10.1177/0961203309350755.

6. Costa-Reis P, Sullivan KE. Genetics and epigenetics of systemic lupus erythematosus. Curr Rheumatol Rep 2013; 15(9): 369 https://doi.org/10.1007/s11926-013-0369-4.

7. Harley JB, Alarcón-Riquelme ME, Criswell LA, Jacob CO, Kimberley RP, Moser KL, et al. Genome-wide association scan in women with systemic lupus erythematosus identifies susceptibility variants in ITGAM, PXK, KIAA1542 and other loci. Nat Genet 2008; 40(2): 204-210. https://doi.org/10.1038/ng.81.

8. Leung Y, Szeto C, Tam L, Lam CWK, Li EK, Wong KC, et al. Urine proteinto-creatinine ratio in an untimed urine collection is a reliable measure of proteinuria in lupus nephritis. Rheumatology (Oxford) 2007; 46(4): 649-652. https://doi.org/10.1093/rheumatology/kel360.

9. Weening JJ, D'Agati VD, Schwartz MM, Seshan SV, Alpers CE, Appel GB, et al. The classification of glomerulonephritis in systemic lupus erythematosus revisited. J Am Soc Nephrol 2004; 15(2): 241-250. https://doi.org/10.1097/01.asn.0000108969.21691.5d.

10. Anolik JH. B cell biology: implications for treatment of systemic lupus erythematosus. Lupus 2013; 22(4): 342-349. https://doi.org/10.1177/0961203312471576.

11. Mohan C, Putterman C. Genetics and pathogenesis of systemic lupus erythematosus and lupus nephritis. Nat Rev Nephrol 2015; 11(6): 329341. https://doi.org/10.1038/nrneph.2015.33.

12. Wu CY, Li CF, Wu QJ, Xu JH, Jiang LD, Gong L, et al. Chinese Systemic Lupus Erythematosus Treatment and Research Group Registry IX: Clinical Features and Survival of Childhood-Onset Systemic Lupus
Erythematosus in China. Chin Med J (Engl) 2017; 130(11): 1276-1282. https://doi.org/10.4103/0366-6999.206346.

13. Kaplan M. STAT4 a critical regulator of inflammation in vivo. Immuno Res 2005; 31(3): 231-242. https://doi.org/10.1385/ir:31:3:231.

14. Abelson AK, Delgado-Vega AM, Kozyrev SV, Sanchez E, Velazquez-Cruz $\mathrm{RV}$, Eriksson $\mathrm{N}$, et al. STAT4 associates with systemic lupus erythematosus through two independent effects that correlate with gene expression and act additively with IRF5 to increase risk. Ann Rheum Dis 2009; 68(11): 1746-1753. https://doi.org/10.1136/ard.2008.097642.

15. Levinson WE. Review of Medical Microbiology and Immunology. 14th ed. New York, USA: McGraw-Hill Education, 2016; 832 p.

16. Hussain N, Jaffery G, Sabri AN, Hasnain S. HLA association in SLE patients from Lahore-Pakistan. Bosn J Basic Med Sci 2011; 11(1): 2026. https://doi.org/10.17305/bjbms.2011.2618.

17. Chai HC, Phipps ME, Chua KH. Genetic risk factors of systemic lupus erythematosus in the Malaysian population: a mini review. Clin Dev Immunol 2012; 2012: 963730. https://doi.org/10.1155/2012/963730.

18. Ceccarelli F, Perricone C, Borgiani P, Ciccacci C, Rufini S, Cipriano E, et al. Genetic factors in systemic lupus erythematosus: Contribution to disease phenotype. J Immunol Res 2015; 2015: 745647 https://doi.org/10.1155/2015/745647.

19. Bolin K, Sandling JK, Zickert A, Jönsen A, Sjöwall C, Svenungsson E, et al. Association of STAT4 polymorphism with severe renal insufficiency in lupus nephritis. PLoS One 2013; 8(12): e84450. https://doi.org/10.1371/journal.pone.0084450.

20. M Carpi F, Di Pietro F, Vincenzetti S, Mignini F, Napolioni V. Human DNA extraction methods: patents and applications. Recent Pat DNA
Gene
Seq
2011
5(1):
$1-7$ https://doi.org/10.2174/187221511794839264.

21. El-Toukhy M, Rageh I, Abdel-Gwad E, Fathy A, El-Shimi O, Roshdy M. STAT4 (RS7582694) gene polymorphism in a group of Egyptian female systemic lupus erythematosus patients. Int J of Adv Res 2016; 4(12): 1837-1842. http://doi.org/10.21474/IJAR01/2590.

22. Rabbani MA, Siddiqui BK, Tahir MH, Ahmad B, Shamim A, Shah SM, et al. Systemic lupus erythematosus in Pakistan. Lupus 2004; 13(10): 820 825. https://doi.org/10.1191/0961203303lu1077xx.

23. Jacobs J, Korswagen LA, Schilder AM, van Tuyl LH, Dijkmans BA, Lems $W F$, et al. Six-year follow-up study of bone mineral density in patients with systemic lupus erythematosus. Osteoporos Int 2013; 24(6): 1827 1833. https://doi.org/10.1007/s00198-012-2157-9.

24. Rúa-Figueroa I, Pego-Reigosa J, López-Longo F, Galindo M, Calvo-Alen J, Campo VD, et al. SAT0391 Cumulative Incidence and Clinical Meaning of Severe Infection in a Large Spanish Cohort of Systemic Lupus Erythematosus. Ann Rheum Dis 2015; 74: 801 http://dx.doi.org/10.1136/annrheumdis-2015-eular.5295.

25. Naheed A, Shaheen JA, Khalid M. Cutaneous manifestations of systemic lupus erythematosus - An experience from Bahawal-Victoria Hospital, Bahawalpur. J Pak Assoc Dermatol 2016; 24(1): 15-20. http://www.jpad.com.pk/index.php/jpad/article/view/167.

26. Solangi GA. Systemic lupus erythematosus at Karachi and Larkana: a comparative study of 94 patients. J Coll Physicians Surg Pak 2001; 11(6): 371-373. https://vlibrary.emro.who.int/imemr/systemic-lupuserythematosus-at-karachi-and-larkana-a-comparative-study-of-94patients/.

27. Gibson K, Goodemote P, Johnson S. FPIN's clinical inquiries: antibody testing for systemic lupus erythematosus. Am Fam Physician 2011; 84(12): 1407-1409. https://pubmed.ncbi.nlm.nih.gov/22230277/.

28. Dema B, Charles N. Autoantibodies in SLE: Specificities, Isotypes and Receptors. Antibodies (Basel) 2016; 5(1): 2 https://doi.org/10.3390/antib5010002.

29. Voulgarelis M, Kokori SI, Ioannidis JP, Tzioufas AG, Kyriaki D, Moutsopoulos HM. Anaemia in systemic lupus erythematosus: aetiological profile and the role of erythropoietin. Ann Rheum Dis 2009; 59(3): 217-222. https://doi.org/10.1136/ard.59.3.217. 
30. Sasidharan PK, Bindya M, Sajeeth Kumar KG. Hematological manifestations of SLE at initial presentation: is it underestimated? ISRN Hematol 2012; 961872. https://doi.org/10.5402/2012/961872.

31. Giannouli S, Voulgarelis M, Ziakas PD, Tzioufas AG. Anaemia in systemic lupus erythematosus: from pathophysiology to clinical assessment. Ann rheum Dis 2006; 65(2): 144-148. https://doi.org/10.1136/ard.2005.041673.

32. Tantawy AA, Salama EI, Mahran MZ, Al-Hefnawy S. Pattern and prognosis of haematological and non-haematological presentatations of juvenile SLE: five years longitudinal study. Egypt Rheumatol Rehabil 2002; 29(5): 755-772. https://vlibrary.emro.who.int/imemr/patternand-prognosis-of-haematological-and-non-haematologicalpresentatations-of-juvenile-slefive-years-longitudinal-study/.

33. Bengtsson A, Sturfelt G, Truedsson L, Blomberg J, Alm G, Vallin H, et al. Activation of type I interferon system in systemic lupus erythematosus correlates with disease activity but not with antiretroviral antibodies. Lupus 2009; 9(9): 664-671. https://doi.org/10.1191/096120300674499064

34. Piotrowski $P$, Lianeri $M$, Wudarski $M$, Olesińska $M$, Jagodziński PP. Contribution of STAT4 gene single-nucleotide polymorphism to systemic lupus erythematosus in the Polish population. Mol Biol Rep 2012; 39(9): 8861-8866. https://doi.org/10.1007/s11033-012-1752-3.

35. Luan H, Li P, Cao C, Li C, Hu C, Zhang S, et al. A single-nucleotide polymorphism of the STAT4 gene is associated with systemic lupus erythematosus (SLE) in female Chinese population. Rheumatol Int 2012; 32(5): 1251-1255. https://doi.org/10.1007/s00296-010-1767-9.

36. Mirkazemi S, Akbarian M, Jamshidi AR, Mansouri R, Ghoroghi S, Salimi Y, et al. Association of STAT4 rs7574865 with Susceptibility to Systemic Lupus Erythematosus in Iranian Population. Inflammation 2013; 36(6): 1548-1552. https://doi.org/10.1007/s10753-013-9698-8.

37. Taylor K, Remmers E, Lee A, Ortmann WA, Plenge RM, Tian C, et al. Specificity of the STAT4 Genetic Association for Severe Disease Manifestations of Systemic Lupus Erythematosus. PLoS Genet 2008; 4(5): e1000084. https://doi.org/10.1371/journal.pgen.1000084.

38. Hellquist A, Sandling J, Zucchelli M, Koskenmies S, Julkunen $H$, $D^{\prime}$ Amato $M$, et al. Variation in STAT4 is associated with systemic lupus erythematosus in a Finnish family cohort. Ann Rheum Dis 2009; 69(5): 883-886. https://doi.org/10.1136/ard.2009.112284.

39. Izadkhasti GR, Kazeminezhad SR, Akhoond MR. Association of STAT4 rs7582694 with susceptibility to systemic lupus erythematosus in population of Lorestan province. J Shahrekord Univ Med Sci 2019; 21(1): 14-18. https://doi.org/10.34172/jsums.2019.03.

40. Xu Q, Tin SK, Sivalingam SP, Thumboo J, Koh DR, Fong KY. Interleukin18 promoter gene polymorphisms in Chinese patients with systemic lupus erythematosus: association with CC genotype at position-607. Ann Acad Med Singap 2007; 36(2): 91-95. https://pubmed.ncbi.nlm.nih.gov/17364073/.

41. Li P, Cao C, Luan H, Li C, Hu C, Zhang S, et al. Association of genetic variations in the STAT4 and IRF7/KIAA1542 regions with systemic lupus erythematosus in a Northern Han Chinese population. Hum Immunol 2011; 72(3): 249-255. https://doi.org/10.1016/j.humimm.2010.12.011.

42. Yamamoto K, Kobayashi H, Arai A, Miura O, Hirosawa S, Miyasaka N. cDNA cloning, expression and chromosome mapping of the human STAT4 gene: both STAT4 and STAT1 genes are mapped to 2 q32.2 $\rightarrow$ q32.3. Cytogenet Cell Genet 1997; 77(3-4): 207-210. https://doi.org/10.1159/000134578.

\section{Authors:}

Hamdan Hamid - M.Phil Immunology \& Molecular Pathology, Assistant Professor, Bakhtawar Amin Medical and Dental College, Multan, Pakistan. https://orcid.org/0000-0002-0454-0210.

Nadeem Afzal - PhD, Professor/Head Department of Immunology, University of Health Sciences, Lahore, Pakistan.
Muhammad Kashif - M.Phil, Assistant professor, Bakhtawar Amin Medical and Dental College, Multan, Pakistan. https://orcid.org/0000-0002-1427$\underline{8893}$.

Muhammad Adil Bashir - M.Phil Immunology, Senior Lecturer, Bakhtawar Amin Medical and Dental College, Multan, Pakistan. https://orcid.org/0000003-3810-2654.

Shah Jahan - PhD, Associate Professor, University of Health Sciences, Lahore, Pakistan. https://orcid.org/0000-0002-1730-5025. 